\title{
Penerapan Model Pembelajaran Group Investigation (GI) untuk Meningkatkan Hasil Belajar Pendidikan Agama Islam
}

\author{
Siti Wasingah \\ SDN Tanggung 1 Kecamatan Kepanjenkidul Kota Blitar \\ Email: sitiwasingah@yahoo.com
}

\section{Tersedia Online di \\ http://www.jurnal.unublitar.ac.id/ index.php/briliant}

\section{Sejarah Artikel}

Diterima pada 14 Juli 2017

Disetuji pada 16 Juli 2017

Dipublikasikan pada: 2 Agustus 2017 Hal 356-370

Kata Kunci:

Group investigation, hasil pelajar, pai.

\begin{abstract}
Abstrak : Penelitian ini bertujuan untuk mendeskripsikan penerapan Model Pembelajaran Group Investigation dalam meningkatkan hasil belajar Pendidikan Agama Islam beserta peningkatannya. Pelaksanaan penelitian dilakukan dalam dua siklus. Peningkatan hasil belajar ditandai dengan peningkatan prosentase hasil kerja kelompok dari siklus I sebesar 79,16 dan meningkat menjadi 86,67 pada siklus II. Hasil ketuntasan belajar pada siklus I sebesar 70,3\% dan meningkat pada siklus II menjadi $82 \%$.
\end{abstract}

Pembelajaraan Pendidikan Agama Islam merupakan suatu kegiatan yang melibatkan seseorang dalam upaya memperoleh pengetahuan, ketrampilan dan nilai-nilai positif dengan memanfaatkan berbagai sumber untuk belajar. Dalam kegiatan pembelajaran ini merujuk pada kegiatan yang didalamnya terdapat integrasi dan interaksi komponen-komponen pembelajaran keagamaan yang dapat dikategorikan menjadi tiga hal pokok yaitu guru, materi pelajaran dan siswa. Interaksi antara tiga komponen utama melibatkan sarana dan prasana seperti metode pembelajaran, media pembelajaran, setting kelas sehingga tercipta situasi pembelajaran yang memungkinkan tercapainya tujuan yang telah direncanakan.

Berhasilnya tujuan pembelajaran di atas ditentukan oleh banyak faktor diantaranya adalah faktor guru dalam melaksanakan proses belajar mengajar, karena guru secara langsung dapat mempengaruhi, membina dan meningkatkan kecerdasan serta keterampilan siswa. Guru bukan hanya sekedar penyampai materi saja, tetapi lebih dari itu guru dapat dikatakan sebagai sentral pembelajaran.

Guru seyogyanya mampu menentukan metode pembelajaran yang dipandang dapat membelajarkan siswa secara aktif melalui proses pembelajaran yang dilaksanakan agar tujuan pembelajaran dapat tercapai secara efektif dan hasil belajarpun dapat lebih ditingkatkan. Hal terpenting dalam kegiatan pembelajaran adalah terjadinya proses belajar (learning proses) pada diri siswa.

Proses pembelajaran Pendidikan Agama Islam yang selama ini dilakukan oleh guru cenderung pada pencapaian target materi kurikulum. Kondisi seperti itu terjadi pula pada kegiatan pembelajaran Pendidikan Agama Islam di kelas VI SDN Tanggung 1 Kecamatan Kepanjenkidul Kota Blitar. Pada awal semester genap pada saat pembelajaran mata pelajaran Pendidikan Agama Islam 
menunjukkan kondisi belajar siswa yang kurang aktif. Banyak siswa mengantuk, tampak diam memperhatikan namun ketika diberi pertanyaan tidak dapat menjawab.

Berdasarkan pengamatan secara langsung ketika pembelajaran PAI, diperoleh data permasalahan sebagai berikut: 1) Beberapa siswa tampak mengantuk ketika pembelajaran PAI. 2) Rendahnya hasil belajar siswa akibat kurangnya minat siswa pada mata pelajaran PAI yang disebabkan oleh proses pembelajaran yang dianggap membosankan.

Melihat kondisi ini, guru sebagai peneliti berupaya memperbaiki proses pembelajaran dengan menggunakan model pembelajaran lain yaitu model pembelajaran yang dapat meningkatkan hasil belajar siswa. Pada penelitian ini guru menggunakan model pembelajaran GI (Group Investigation)

GI merupakan model pembelajaran dengan siswa belajar secara kelompok, kelompok belajar terbentuk berdasarkan topik yang dipilih siswa. Pendekatan ini memerlukan norma dan struktur yang lebih rumit daripada pendekatan yang lebih berpusat pada guru. Dalam pembelajaran kooperatif GI siswa dibagi menjadi beberapa kelompok dengan anggota 2-6 orang siswa yang heterogen. Kelompok memilih topik untuk diselidiki dan melakukan penyelidikan yang mendalam atas topic yang dipilih, selanjutnya menyiapkan dan mempresentasikan laporan di depan kelas, Wiratama (2014)

Group Investigation (Investigasi Kelompok) adalah model belajar kooperatif yang menempatkan siswa ke dalam kelompok secara heterogen dilihat dari perbedaan kemampuan dan latar belakang yang berbeda baik dari segi gender, etnis, dan agama untuk melakukan investigasi terhadap suatu topic (Eggen dan Kauchak dalam Harisantoso, $2005: 2$ )

Dalam penerapan tipe investigasi kelompok guru membagi kelas menjadi kelompok-kelompok dengan anggota 5-6 siswa yang heterogen menyesuaikan jumlah siswa dalam kelas. Kelompok di sini dapat dibentuk dengan mempertimbangkan keakraban persahabatan atau minat yang sama dalam topic tertentu. Selanjutnya siswa memilih topik untuk diselidiki dan melakukan penyelidikan yang mendalam atas topik yang dipilih kemudian mempresentasikan laporannya kepada seluruh kelas.

Adapun Langkah model GI Menurut Slavin (dalam Vierwinto, 2012) membagi langkah-langkah pelaksanaan model investigasi kelompok meliputi 6 (enam) tahapan. Yaitu : 1) Mengidentifikasikan topik dan membuat kelompok 2) Merencanakan tugas yang akan dipelajari 3) Melaksanakan investigasi 4) Menyiapkan laporan akhir 5) Mempresentasikan laporan akhir 6) Evaluasi.

Peneliti memilih menerapkan Model GI didasari oleh berbagai keunggulan model tersebut. Menurut Rusman (dalam Devi, 2013) keunggulan model pembelajaran kooperatif tipe GI sebagai berikut : 1) Dapat dipakai untuk tanggung jawab dan kreatifitas siswa, baik secara perorangan maupun individu. 2) Membantu terjadinya pembagian tanggung jawab ketika siswa mengikuti pembelajaran dan berorientasi menuju pembentukan manusia sosial. 3) Memberikan kesempatan berkolaborasi dengan teman sebaya dalam bentuk diskusi kelompok untuk memecahkan suatu masalah. 4) Serta mengaktifkan siswa dalam proses pembelajaran yang diberikan guru sehingga dapat membangun pengetahuan siswa. 
Penelitian ini bertujuan: a)mendeskripsikan penerapan model pembelajaran Group Investigation dalam upaya meningkatkan hasil belajar Pendidikan Agama Islam pada siswa kelas VI SDN Tanggung 1 Kota Blitar b)Mengetahui peningkatan hasil belajar siswa kelas VI SDN Tanggung 1 Kota Blitar setelah diajarkan dengan model pembelajaran Group Investigation. Peneliti berharap bahwa penelitian ini dapat memberian manfaat khususnya bagi guru sebagai peneliti, siswa dan sekolah.

\section{METODE}

\section{Lokasi, Waktu dan Subjek Penelitian}

Penelitian ini dilakukan di SDN Tanggung 1 Kecamatan Kepanjenkidul Kota Blitar, yang beralamat di Jalan Ciliwung No. 296 Kota Blitar. Waktu penelitian yaitu pada bulan Maret sampai dengan April dengan rincian tindakan sebagai berikut : Siklus I pertemuan ke-1 pada tanggal 27 Maret 2017, Siklus I pertemuan ke-2 pada tanggal 3 April 2017. Siklus II pertemuan ke-1 dilaksanakan pada tanggal 10 April 2017 dan dilanjutkan dengan Siklus II pertemuan ke-2 pada tanggal 17 April 1017. Subjek penelitian ini adalah Guru Pendidikan Agama Islam di SDN Tanggung 1 Kota Blitar dan siswa kelas VI yang berjulah 34.

\section{Prosedur Penelitian}

Pendekatan yang digunakan pada penelitian ini pendekatan deskriptif kualitatif yaitu penelitian yang menggambarkan bagaimana suatu model pembelajaran diterapkan dan bagaimana hasil yang diharapkan dapat tercapai. Jenis Penelitian ini merupakan penelitian tindakan (action research), karena penelitian dilakukan untuk memecahkan masalah pembelajaran di kelas.

Menurut Oja dan Smulyan (dalam Sukidin, 2002:55) mengelompokkan penelitian tindakan menjadi empat macam, yaitu (a) guru sebagai peneliti, (b) penelitian tindakan kolaboratif, (c) simultan teritegratif, dan (d) administrasi sosial eksperimental.

Dalam penelitian tindakan ini menggunakan bentuk penelitian kolaboratif dimana peneliti bertindak sebagai guru dengan guru kelas VI sebagai pengamat. Penanggung jawab penuh penelitian tindakan adalah peneliti. Tujuan utama dari penelitian tindakan ini adalah meningkatkan hasil pembelajaran Pendidikan Agama Islam di kelas VI. Peneliti secara penuh terlibat dalam penelitian mulai dari perencanaan, tindakan, pengamatan dan refleksi.

\section{Langkah-langkah Penelitiaan}

Peneliti menggunakan beberapa tahapan mulai dari perencanaan, pelaksanaan, pengamatan, dan refleksi seperti yang dijelaskan oleh Arikunto (2010: 17). Tahapan yang dilaksanakan oleh peneliti secara lebih rinci sebagai berikut.

\section{Tahap Perencanaan (Planing)}

Tahap perencanaan kegiatan yang dilakukan peneliti adalah menyusun rancangan untuk menentukan langkah-langkah yang akan dilakukan dalam tindakan. Perencanaan tersebut meliputi pengkajian Standar Kompetensi dan Kompetensi Dasar, penyusunan RPP, penetapan target keberhasilan pembelajaran dan membuat instrument pengamatan untuk merekam fakta yang terjadi selama proses pembelajaran. 


\section{Tahap Pelaksanaan (Acting)}

Pelaksanaan tindakan penelitian ini dilaksanakan dalam dua siklus, masing-masing siklus terdiri atas dua pertemuan. Tahap rancangan yang dilaksanakan dalam tahap pelaksanaan menjelaskan mengenai langkah-langkah kegiatan yang harus dilakukan oleh guru dan siswa untuk meningkatkan hasil belajar Pendidikan Agama Islam materi surah pendek pilihan melalui model pembelajaran Group Investigation.

\section{Tahap Pengamatan (Observation)}

Tahap ketiga dalam PTK adalah pengamatan. Pengamatan atau observasi yang dimaksud pada tahap III adalah pengumpulan data. Dalam proses pengumpulan data, peneliti melakukan pengamatan dan mencatat semua hal yang terjadi selama pelaksanaan kegiatan berlangsung untuk memperoleh data yang akurat untuk perbaikan siklus selanjutnya. Kegiatan pengamatan atau observasi dilaksanakan secara kolaboratif untuk mengamati keterampilan guru, serta hasil belajar siswa pada Pendidikan Agama Islam materi Zakat dengan model pembelajaran Group Investigation.

\section{Tahap Refleksi (Reflecting)}

Pada tahap refleksi peneliti melakukan evaluasi terhadap apa yang telah dilakukan. Selain itu peneliti juga menganalisis kekurangan pada pelaksanaan pembelajaran yang telah dilakukan untuk diperbaiki pada siklus selanjutnya sampai masalah yang diteliti dapat dipecahkan secara optimal. 


\section{Instrumen Penelitian dan Teknik Pengumpulan Data}

Instrumen dalam penelitian ini adalah dengan menggunakan (1) teknik observasi, (2) teknik dokumentasi, (3) tes, dan (4) angket respon siswa.

\section{Analisis Data}

Analisis data dilakukan setelah pelaksanaan tindakan setiap siklus. Teknik analisis data yang digunakan dalam penelitian ini adalah teknik analisis data deskriptif kualitatif, yaitu (1) reduksi data, (2) penyajian data, dan (3) penarikan kesimpulan.

Analisis data yang berasal dari observasi guru menguraikan data yang telah dibuat pengamat. Aspek-aspek yang diamati dijelaskan secara terperinci dalam lampiran. Penilaian pada observasi guru adalah skor yang diperoleh dibagi skor maksimum dan dikalikan 100. Apabila hasil yang diperoleh lebih dari $75 \%$ dari skor total maka guru sudah menerapkan model Group Investigation dengan baik.

Data hasil observasi siswa diambil dari nilai aktivitas siswa saat proses pembelajaran berlangsung. Penilaian aktivitas siswa diperoleh dengan skor yang diperoleh dibagi dengan skor maksimum dikali 100. Apabila hasil presentase menunjukkan kenaikkan pada setiap siklus maka kegiatan yang dilakukan siswa sudah baik

Peningkatan hasil belajar siswa dapat diketahui dari hasil tes yang dicari nilai rata-ratanya. Tes yang kami maksudkan di sini meliputi tes lisan dan tes tulis. Tes lisan untuk kengetahui kemampuan membaca siswa tentan surat-surat pendek pilihan. Tes tulis digunakan untuk mengetahui kemampuan siswa tentang surat pendek secara umum. Untuk peningkatan hasil belajar maka digunakan nilai yang diperoleh siswa yang disesuaikan dengan KKM sebagai indikator peningkatan hasil.

Ketuntasan belajar siswa merupakan pemahaman siswa secara penuh terhadap suatu materi yang dibuktikan degan hasil belajar yang baik pada materi tersebut. Patokan penilaian menggunakan Kriteria Ketuntasan Minimal (KKM) yang ditentukan oleh SDN Tanggung 1 Kota Blitar. Siswa dikatakan tuntas belajar apabila nilai akhir siswa mencapai nilai $\geq 70$. Secara klasikal dalam satu kelas dianggap telah tuntas jika siswa yang mendapat nilai $\geq 70$ memperoleh persentase $80 \%$ dari siswa satu kelas. Hal ini artinya 80\% dari seluruh kelas memperoleh nilai akhir $\geq 70$. Untuk mengetahui ketuntasan belajar secara klasikal dapat menggunakan rumus sebagai berikut.

Langkah-langkah analisis terdiri dari tiga alur kegiatan yang terjadi secara bersamaan yaitu : (1) reduksi data, (2) penyajian data, (3) penarikan kesimpulan. Tahap pertama dari kegiatan analisis data deskriptif kualitatif yaitu melakukan reduksi data. Reduksi data adalah proses menyeleksi data yang sudah terkumpul, memfokuskan dan menyederhanakan data sampai penyusunan data. Data yang telah terkumpul diklasifikasikan berdasarkan jenisnya atau aspek yang diamati yang bertujuan memudahkan peneliti menarik kesimpulan.

Langkah kedua dalam kegiatan analisis data deskriptif kualitatif adalah melakukan penyajian data. Penyajian data dilakukan dengan menyusun dalam bentuk tabel dan narasi, lalu dibandingkan dan dipadukan dengan berbagai informasi atau data yang diperoleh dari hasil reduksi data hingga memberi kemungkinan adanya penarikan kesimpulan dan pengambilan tindakan. Informasi 
tersebut berupa uraian kegiatan pembelajaran, aktivitas siswa dalam pembelajaran, respon siswa terhadap pembelajaran yang dilakukan, serta hasil yang diperoleh siswa.

Penarikan kesimpulan adalah pengambilan inti dari data-data yang telah dikumpulkan. Peneliti ini melakukan penilaian tentang hasil belajar siswa dalam Mata Pelajaran Pendidikan Agama Islam melalui model pembelajaran Group Investigation. Penarikan kesimpulan dilihat dari hasil ketuntasan siswa baik secara individu maupun klasikal selama pembelajaran.

\section{HASIL}

Data yang diuraikan pada tahap ini adalah data yang diperoleh dari tahap tindakan siklus I pertemuan pertama dan pertemuan kedua, refleksi siklus I dan data yang diperoleh dari tahap tindakan siklus II pertemuan pertama, pertemuan kedua, refleksi siklus II.

\section{Siklus I Pertemuan Ke-1}

Pada tahap perencanaan ini peneliti (1) menentukan materi yaitu Pengertian Zakat. (2) menyiapkan silabus sebagai bahan acuan pengembangan RPP (3) merancang Rencana Pelaksanaan Pembelajaran (RPP) dengan model pembelajaran Group Investigation, (4) menyiapkan nama kelompok dari kertas untuk dipasang di meja tiap kelompok (5) menyiapkan lembar kerja kelompok, kunci jawaban kerja kelompok, lembar tes individu, kunci jawaban tes individu (6) menyiapkan alat atau instrumen pengumpul data yang akan digunakan untuk pengumpulan data yaitu berupa lembar observasi aktivitas guru dan siswa selama proses pembelajaran dengan menggunakan model pembelajaran Group Investigation, lembar catatan lapangan, lembar angket respon siswa serta kamera untuk keperluan dokumentasi berupa foto saat kegiatan pembelajaran.

Siklus I pertemuan 1 dilaksanakan pada Hari Senin, 27 Maret 2017 selama 3x35 menit pada jam keempat dan jam kelima. Kegiatan diawali dengan salam, presensi, apersepsi, menyampaikan informasi materi yang akan dilaksanakan, dan tujuan dari kegiatan yang akan dilaksanakan. Selanjutnya pada kegiatan inti guru membagi siswa menjadi 6 kelompok dengan anggota 6 siswa dalam setiap kelompok.

Guru memberi nama setiap kelompok tersebut dengan nama-nama abjad yaitu Kelompok A, Kelompok B, kelompok C, Kelompok D, dan Kelompok E. Kelompok F. Anggota kelompok diupayakan heterogen dalam hal gender dan kemampuan akademik.

Pada fase merencanakan tugas atau fase ke-3 dalam langkah GI, guru mempersiapkan dan menata sumber belajar sebagai sarana siswa berfantasi agar dapat berinvestigasi secara optimal. Guru membagi tugas kepada enam kelompok dengan pembagian kelompok A, B, C mempelajari dan membuat resume tentang pengertian zakat, sementara kelompok $\mathrm{D}, \mathrm{E}$ dan $\mathrm{F}$ mempelajari dan membuat resume tentang hukum membayar zakat.

Pada fase keempat siswa bersama kelompoknya berkesempatan menganalisis, mengerjakan tugas bersama kelompoknya berdasarkan berbagai sumber belajar yang ada missal dari buku pelajaran atau dari buku di perpustakaan.

361 BRILIANT: Jurnal Riset dan Konseptual Volume 2 Nomor 3, Agustus 2017 
Pada fase kelima masing-masing kelompok diberi kesempatan mempresentasikan hasil kerjanya di depan kelas sementara kelompok lain memberikan tanggapan. Guru memberikan reinforcement pada kelompok yang penampilannya baik dan memberikan motivais pada kelompok yang kurang baik. Guru memberikan penegasan terhadap masing-masing bahasan dari setiap kelompok.

Pada fase terakhir siswa berkesempatan menyimpulkan materi pembelajaran yang telah dipelajari. Guru membantu siswa melakukan refleksi terhadap pembelajaran yang telah dipelajari dan kemudian bersama siswa menyimpulkan pembelajaran. Pada akhir kegiatan ini guru mengevaluasi pembelajaran yang telah dilakukan dengan menggunakan tes individu/tes hasil belajar

Penilaian aktivitas guru menggunakan lembar observasi guru yang diisi oleh observer yaitu guru kelas lima. Aspek yang diamati dalam lembar observasi guru dengan menerapkan model pembelajaran Group Investigation sebanyak sepuluh aspek yang meliputi tahapan-tahapan dalam GI. Dari sepuluh aspek tersebut, enam aspek telah muncul yaitu merencanakan tahapan pembelajaran, memusatkan perhatian siswa, mempersiapkan dan menata sumber belajar sebagai sarana siswa berfantasi agar dapat berinvestigasi secara optimal, membuat penyelidikan (Memfasilitasi, membimbing serta mengawasi siswa ), memberikan reinforcement pada kelompok yang penampilannya baik dan memberikan motivasi pada kelompok yang kurang baik, dan mengevaluasi pembelajaran yang telah dilakukan dengan menggunakan tes hasil belajar.

Penilaian observer dalam lembar observasi aktivitas siswa terdapat sepuluh aspek. Kesepuluh aspek tersebut merupakan respon dari aktivitas yang dilaksanakan guru dalam proses pembelajaran mulai dari kegiatan awal, kegiatan inti dan kegiatan akhir. Dari kesepuluh aspek tersebut terdapat enam aspek yang sudah muncul dan ada empat aspek yang belum muncul. Di antara sepuluh aspek yang belum muncul yaitu siswa belum tampak aktif ketika proses pembelajaran berlangsung dan belum berani untuk mengungkapkan pendapat terhadap jawaban kelompok lain.

Hasil penilaian observer terhadap aktivitas siswa dalam pelaksanaan pembelajaran model Group Investigation pada Siklus I pertemuan 1 mencapai prosentase $60 \%$ termasuk dalam kriteria cukup baik.

Hasil penilaian sikap siswa pada siklus I pertemuan 1 diperoleh data bahwa pada aspek disiplin mencapai $61,76 \%$ termasuk dalam kriteria cukup baik (C) namun masih perlu ditingkatkan kembali. Pada aspek tanggung jawab siswa mencapai 60,78\% atau cukup baik (C). Pada aspek komunikatif mencapai 44,12\% atau termasuk kategori kurang baik. Dari data tersebut dapat diketahui bahwa siswa kurang komunikatif ketika pembelajaran berlangsung. Hal tersebut menunjukkan bahwa pembelajaran selama ini belum pernah mengguakan GI

Hasil yang diperoleh adalah kelompok A mendapatkan nilai 100, kelompok B mendapatkan nilai 70, kelompok C mendapatkan nilai 70, kelompok D mendapatkan nilai 100, kelompok E mendapatkan nilai 40 dan kelompok $F$ mendapat nilai 70 .

Hasil tes tulis siswa kelas VI SDN Tanggung 1 pada siklus I pertemuan 1 memperoleh nilai total sebesar 2840 dengan nilai rata-rata 84 . Siswa yang tuntas mencapai 23 siswa atau sebesar $67,65 \%$.

362 BRILIANT: Jurnal Riset dan Konseptual Volume 2 Nomor 3, Agustus 2017 
Catatan Lapangan yang Terjadi Pada Guru, Siswa, dan Proses Pembelajaran Pendidikan Agama Islam melalui model Pembelajaran Group Investigation yaitu guru sudah membuka pembelajaran dengan baik. Guru perlu meningkatkan kegiatan untuk memantau kedisiplinan siswa dan keterampilan dalam mengkondisikan kelas. Motivasi yang diberikan guru kepada siswa ketika proses pembelajaran dengan menggunakan model pembelajaran Group Investigation dapat meningkatkan semangat siswa dalam belajar. Kegiatan diskusi kelompok pada pertemuan ini sudah meningkat terlibat dalam diskusi tidak ada siswa yang masih sibuk bermain sendiri. Pada pertemuan ini siswa terlihat lebih antusias sehingga proses pembelajaran berjalan lebih menyenangkan.

Di dalam angket siswa terdapat sepuluh pernyataan mengenai pendapat siswa terhadap pelaksanaan pembelajaran dengan menerapkan model Group Investigation. Hasil tersebut menunjukkan $82 \%$ siswa telah memberikan respon positif.

\section{Siklus I Pertemuan 2}

Perencanaan siklus I pertemuan 2 peneliti tetap menggunakan model pembelajaran Group Investigation untuk mengatasi masalah yang muncul pada kegiatan siklus I pertemuan 1. Pada perencanaan ini peneliti melakukan: (1) menentukan materi yang akan dipelajari 2) merancang Rencana Pelaksanaan Pembelajaran (RPP) dengan model pembelajaran Group Investigation, (3) menyiapkan Lembar Kerja Kelompok (4) menyiapkan lembar kerja individu (5) menyiapkan alat atau instrumen pengumpul data yang akan digunakan seperti pada siklus I pertemuan 1 .

Siklus I pertemuan 2 dilaksanakan pada tanggal 3 April 2017 selama $3 \times 35$ menit. Kegiatan pada siklus I pertemuan 2 seperti halnya pada pertemuan 1 dengan menggunakan materi yang telah dipilih yaitu macam-macam zakat

Kegiatan ini diawali dengan fase ke-1 memusatkan perhatian. Fase ke-2 guru menuliskan tujan pembelajaran di papan tulis. Kemudian secara klasikal guru membimbing siswa untuk membaca buku pelajaran, menganalisis materi. Setelah itu guru memanggil perwakilan kelompok untuk menerima tugas kelompok.

Pada fase ke-3 yaitu tahap merencanakan tugas. Setiap kelompok mendapat tugas yang berbeda. Kelompok A mendapat tugas meresum dan memuat peta konsep tentang macam-macam zakat. Kelompok B bertugas meresum zakat emas dan perak. Kelompok $\mathrm{C}$ bertugas meresum zakat hasil pertanian. Kelompok D bertugas meresum zakat binatang ternak. Kelompok E bertugas meresum zakat hasil perdagangan. Kelompok F bertugas meresum zakat hasil temuan atau rikaz.

Pada fase keempat siswa berkesempatan menganalisis, berdiskusi dan meresum hasil diskusi mereka. Guru memfasilitasi, membimbing serta mengawasi siswa yang sedang berfantasi dan berinvestigasi agar setiap kelompok dpaat bekerja optimal.

Penilaian aktivitas guru menggunakan lembar observasi guru yang diisi oleh observer yaitu guru kelas lima. Aspek yang diamati dalam lembar observasi guru dengan menerapkan model pembelajaran Group Investigation sebanyak sepuluh aspek yang meliputi tahapan-tahapan dalam GI. Dari sepuluh aspek tersebut, tujuh aspek telah muncul yaitu merencanakan tahapan pembelajaran, memusatkan perhatian siswa, mengidentifikasi topik dan membagi siswa ke dalam

363 BRILIANT: Jurnal Riset dan Konseptual Volume 2 Nomor 3, Agustus 2017 
kelompok, membuat penyelidikan (Memfasilitasi, membimbing serta mengawasi siswa), Memberikan penegasan terhadap masing-masing bahasan dari setiap kelompok, memberikan reinforcement pada kelompok yang penampilannya baik dan memberikan motivasi pada kelompok yang kurang baik, dan mengevaluasi pembelajaran yang telah dilakukan dengan menggunakan tes hasil belajar.

Penilaian observer dalam lembar observasi aktivitas siswa terdapat sepuluh aspek. Kesepuluh aspek tersebut merupakan respon dari aktivitas yang dilaksanakan guru dalam proses pembelajaran mulai dari kegiatan awal, kegiatan inti dan kegiatan akhir. Hasil penilaian observer terhadap aktivitas siswa dalam pelaksanaan pembelajaran model pembelajaran Group Investigation. pada Siklus pertama pertemuan kedua mencapai prosentase $70 \%$ termasuk dalam kriteria baik.

Hasil penilaian sikap siswa pada siklus I pertemuan 2 diperoleh data bahwa pada aspek disiplin mencapai $82 \%$ termasuk dalam kriteria baik (B). Pada aspek tanggung jawab siswa mencapai $71 \%$ atau baik (B). Pada aspek komunikatif mencapai $61 \%$ atau termasuk kategori cukup baik.

Hasil yang diperoleh adalah kelompok A mendapatkan nilai 100, kelompok B mendapatkan nilai 80, kelompok C mendapatkan nilai 90, kelompok D mendapatkan nilai 90, kelompok E mendapatkan nilai 70 dan kelompok $\mathrm{F}$ mendapat nilai 70 .

Hasil tes tulis siswa kelas VI SDN Tanggung 1 pada siklus I pertemuan ke-2 memperoleh nilai total sebesar 2870 dengan nilai rata-rata 85 . Siswa yang tuntas mencapai 25 siswa atau sebesar $73 \%$.

Catatan Lapangan : guru sudah membuka pembelajaran dengan baik. Guru perlu meningkatkan kegiatan untuk memantau kedisiplinan siswa. Guru juga harus lebih meningkatakan motivasi kepada siswa ketika proses pembelajaran dengan menggunakan model pembelajaran Group Investigation berlangsung agar semua siswa dapat terlibat dalam diskusi sehingga tidak ada siswa yang masih sibuk bermain sendiri atau hanya sekedar bergabung dalam kelompok tanpa terlibat aktif untuk mencari jawaban dari soal yang diberikan.

Di dalam angket siswa terdapat sepuluh pernyataan mengenai pendapat siswa terhadap pelaksanaan pembelajaran dengan menerapkan model Group Investigation. Hasil tersebut menunjukkan $87,3 \%$ siswa telah memberikan respon positif.

Berdasarkan hasil observasi dan analisis data serta data pendukung pada siklus I pertemuan 1 dan pertemuan 2 maka refleksi pada siklus I adalah sebagai berikut: (1) langkah-langkah pembelajaran yang dilaksankan guru dengan menggunakan model Group Investigation sudah mengalami peningkatan dari pertemuan 1 ke pertemuan 2, namun guru masih perlu meningkatkan hasil yang diperoleh untuk aspek yang belum nampak, (2) hasil belajar siswa pada siklus I pertemuan 2 menunjukkan peningkatan, tetapi masih ada beberapa aspek yang belum nampak diantaranya siswa belum berani untuk menyampaikan pendapat terhadap jawaban kelompok lain, siswa masih ragu dan kurang berani untuk menyampaikan kesan atau pendapat mengenai pembelajaran.

\section{Siklus II Pertemuan ke-1}

Perencanaan siklus II pertemuan 1 peneliti menggunakan model pembelajaran Group Investigation. Pada perencanaan ini peneliti melakukan: (1)

364 BRILIANT: Jurnal Riset dan Konseptual Volume 2 Nomor 3, Agustus 2017 
menentukan materi pembelajaran yaitu tentang Zakat Fitrah (2) merancang Rencana Pelaksanaan Pembelajaran (RPP) dengan model pembelajaran Group Investigation, (3) menyiapkan Lembar Kerja Kelompok (4) menyiapkan lembar kerja individu (5 menyiapkan alat atau instrumen pengumpul data yang akan digunakan seperti pada siklus I.

Siklus II pertemuan 1 dilaksanakan pada tanggal 10 April 2017 selama 3x35 menit. Kegiatan pada siklus II pertemuan 1 seperti halnya pada pertemuan sebelumnya dengan menggunakan materi yang telah dipilih yaitu mempelajari tentang zakat fitrah.

Pada fase pertama guru memotivasi siswa (memfokuskan perhatian siswa) dengan cara tanya jawab berkaitan dengan materi zakat maal/zakat harta. Guru juga menyampaikan tujuan pembelajaran.

Pada fase kedua guru mengidentifikasi topic dan membagi siswa ke dalam kelompok. Pembentukan kelompok tetap seperti pada pertemuan pertama. Selanjutnya guru memanggil ketua kelompok untuk menerima LKK. Pembagian tugas tidak seperti pada pertemuan sebelumnya yang diurutkan dari materi pertama dibahas oleh kelompok A, dst. Pembagian diurutkan dari belakang. Kelompok $\mathrm{F}$ mendapat tugas untuk mendiskusikan dan meresum tentang definisi zakat fitrah. Kelompok E mendapat tugas untuk mendiskusikan dan meresum tentang syarat wajib zakat fitrah. Kelompok D mendapat tugas untuk mendiskusikan dan meresum tentang waktu membayar zakat fitrah. Kelompok C mendapat tugas untuk membahas dan membuat resume tentang jumlah zakat fitrah yang wajib dikeluarkan. Kelompok B bertugas untuk mendiskusikan tentang zakat profesi. Kelompok A bertugas untuk membahas tentang dalil tentang zakat Fitrah.

Pada fase berikutnya siswa bersama kelompoknya mengerjakan tugas kelompok, berdiskusi dan menganalisis kemudian membuat resume atas kerja kelompoknya. Guru membimbing tiap kelompok untuk menyelesaikan tugasnya.

Pada fase kelima siswa diberi kesempatan untuk mempresentasikan hasil kerja kelompoknya. Anggota dari kelompok lain dipersilakan untuk menanggapi. Guru kemudian memberi penguatan materi.

Penilaian aktivitas guru menggunakan lembar observasi guru. Aspek yang diamati dalam lembar observasi guru dengan menerapkan model pembelajaran Group Investigation sebanyak sepuluh dan semua aspek telah muncul, sehingga tingkat keberhasilan 100\%.

Penilaian aktivitas siswa menggunakan lembar observasi siswa. Berdasarkan data pada lembar observasi siswa terdapat 10 aspek yang diamati 1 aspek mendapatkan nilai 0 atau belum tampak yaitu aspek siswa berani mengungkapkan kesan dan saran mengenai pembelajaran. Sehingga hasil observasi siswa yang dilakukan secara klasikal pada siklus II pertemuan 1 memperoleh nilai prosentase sebesar $90 \%$.

Hasil penilaian sikap siswa pada siklus II pertemuan 1 diperoleh data bahwa pada aspek disiplin mencapai $85 \%$ termasuk dalam kriteria sangat baik (A). Pada aspek tanggung jawab siswa mencapai $85 \%$ atau sangat baik (A). Pada aspek komunikatif mencapai $78 \%$ atau termasuk kategori baik. Dari data tersebut dapat diketahui bahwa aktivitas siswa telah meningkat dalam hal kedisiplinan, tanggung jawab dan komunikasi.

365 BRILIANT: Jurnal Riset dan Konseptual Volume 2 Nomor 3, Agustus 2017 
Hasil yang diperoleh yaitu kelompok A mendapatkan nilai 100, kelompok B mendapatkan nilai 100, kelompok C mendapatkan nilai 100, kelompok D mendapatkan nilai 60, kelompok E mendapatkan nilai 100, kelompok F mendapatkan nilai 60 .

Hasil tes tulis siswa kelas V SDN Tanggung 1 pada siklus II pertemuan 1 memperoleh nilai total sebesar 3040 dengan nilai rata-rata 89. Dengan jumlah siswa tuntas sebanyak 26 atau dengan tingkat keberhasilan sebesar $76 \%$. Hasil tersebut menunjukkan kenaikan jika dibandingkan dengan pertemuan sebelumnya.

Pada bagian ini membahas mengenai catatan lapangan yang terjadi pada guru, siswa, dan proses pembelajaran Pendidikan Agama Islam melalui model pembelajaran Group Investigation, dan angket respon siswa. Bagian-bagian tersebut akan dijabarkan sebagai berikut:

Guru sudah membuka pembelajaran dengan baik. Guru sudah meningkatkan kegiatan untuk memantau kedisiplinan siswa dan keterampilan dalam mengkondisikan kelas. Motivasi yang diberikan guru kepada siswa ketika proses pembelajaran dengan menggunakan model pembelajaran Group Investigation dapat meningkatkan semangat siswa dalam belajar. Kegiatan diskusi kelompok pada pertemuan ini sudah meningkat. Semua siswa terlibat dalam diskusi tidak ada siswa yang masih sibuk bermain sendiri. Pada pertemuan ini siswa terlihat lebih antusias sehingga proses pembelajaran berjalan lebih menyenangkan.

Secara klasikal pembelajaran pada siklus II pertemuan 1 dikatakan belum tuntas karena siswa yang tuntas belum mencapai $80 \%$. Oleh karena itu peneliti perlu melakukan perbaikan pada pertemuan berikutnya.

Hasil angket respon siswa pada siklus I pertemuan 2 menunjukan hasil bahwa 95 persen telah memberikan jawaban positif.

\section{Siklus II Pertemuan Ke-2}

Perencanaan siklus II pertemuan 2 peneliti menggunakan model pembelajaran Group Investigation. Pada perencanaan ini peneliti melakukan: (1) menentukan materi pembelajaran yaitu kelanjutan materi sebelumnya yaitu tentang mustahik zakt (2) merancang Rencana Pelaksanaan Pembelajaran (RPP) dengan model pembelajaran Group Investigation, (3) menyiapkan Lembar Kerja Kelompok (4) menyiapkan lembar kerja individu (5) menyiapkan alat atau instrumen pengumpul data yang akan digunakan seperti pada siklus I.

Pelaksanaan Tindakan Siklus II pertemuan ke-2 dilaksanakan pada tanggal 17 Maret 2017 selama 3x35 menit. Kegiatan pada siklus II pertemuan 2 seperti halnya pada pertemuan sebelumnya. Kegiatan pembelajaran diawali dengan salam, absensi siswa dan apersepsi. Guru juga menyampaikan informasi materi dan tujuan pembelajaran hari itu. Pada apersepsi guru memperdengarkan bertanya jawab tentang materi zakat fitrah. Setelah itu guru memfokuskan perhatian siswa untuk membaca materi dari buku tentang mustahik zakat, serta menyampaikan tujuan pembelajaran.

Guru meminta perwakilan kelompok untuk menerima Lembar Kerja Kelompok. Setiap kelompok bertugas untuk mendiskusikan, menganalisis dan membuat resume tentang orang yang berhak menerima zakat (mustahik zakat). 
Pada fase ketiga dan keempat siswa mengerjakan tugas kelompok. Siswa bersama kelompoknya menganalisis dan mendiskusikan tugasnya. Guru membimbing siswa dan mengamatik aktivitas siswa.

Pada tahap selanjutnya siswa dari masing-masing kelompok dipersilahkan mempresentasikan hasil kerja kelompoknya. Sementara anggota dari kelompok lain berkesempatan untuk menanggapi kelompok tersebut.

Penilaian aktivitas guru menggunakan lembar observasi guru. Aspek yang diamati dalam lembar observasi guru dengan menerapkan model pembelajaran Group Investigation sebanyak 10 aspek yang meliputi langkahlangkah dalam pembelajaran Group Investigasi telah muncul semua atau dengan tingkat keberhasilan 100\%

Penilaian aktivitas siswa menggunakan lembar observasi siswa. Berdasarkan data pada lembar observasi siswa terdapat 10 aspek dan semua aspek sudah mendapat nilai satu atau sudah muncul. Ini berarti tingkat keberhasilan yang diperoleh $100 \%$ atau dengan kategori sangat baik.

Hasil penilaian sikap siswa pada siklus II pertemuan 2 diperoleh data bahwa pada aspek disiplin mencapai $96 \%$ termasuk dalam kriteria sangat baik (A). Pada aspek tanggung jawab siswa mencapai 95\% atau sangat baik (A). Pada aspek komunikatif mencapai $84 \%$ atau termasuk kategori baik. Data ini dapat dilihat pada tabel 4.26. Dari data tersebut dapat diketahui bahwa sikap siswa telah mengalami peningkatan yang sangat baik.

Hasil yang diperoleh yaitu kelompok A mendapatkan nilai 100, kelompok B mendapatkan nilai 100, kelompok C mendapatkan nilai 100, kelompok D mendapatkan nilai 100, kelompok E mendapatkan nilai 100, kelompok F mendapatkan nilai 100.

Hasil tes tulis siswa kelas V SDN Tanggung 1 pada siklus II pertemuan 2 memperoleh nilai total sebesar 3160 dengan nilai rata-rata 93. Siswa tuntas sebanyak 30 siswa atau mencapai ketuntasan klasikal sebesar $88 \%$

Guru sudah membuka pembelajaran dengan baik. Guru sudah meningkatkan kegiatan untuk memantau kedisiplinan siswa dan keterampilan dalam mengkondisikan kelas. Kegiatan diskusi kelompok pada pertemuan ini sangat baik. Semua siswa terlibat dalam diskusi tidak ada siswa yang masih sibuk bermain sendiri. Pada pertemuan ini siswa terlihat lebih antusias sehingga proses pembelajaran berjalan lebih menyenangkan.

Hasil angket respon siswa pada siklus II pertemuan 2 menunjukan hasil bahwa respon siswa terhadap pembelajaran Group Investigation sebesar 98\% telah memberikan respon positif.

Berdasarkan hasil observasi, analisis data serta data pendukung pada siklus II pertemuan 1 dan pertemuan 2 refleksi yang dilakukan sebagai berikut: (1) aktivitas guru mengenai langkah-langkah pembelajaran menggunakan model Group Investigation sudah mengalami peningkatan dari pertemuan $1 \mathrm{ke}$ pertemuan 2 sehingga hasil yang diperoleh guru sudah mendapatkan nilai yang sangat baik, (2) hasil belajar siswa pada siklus II pertemuan 2 menunjukkan nilai akhir rata-rata kelas pada siklus II pertemuan 1 yakni 82,58 dan pada siklus II pertemuan 2 meningkat menjadi 88,39 (3) aktivitas siswa dalam proses pembelajaran Group Investigation sudah menunujukkan peningkatan sehingga pada siklus II pertemuan 2 semua aspek dalam aktivitas siswa sudah tampak. 


\section{PEMBAHASAN}

\section{Data keterlaksanaan proses pembelajaran menggunakan model pembelajaran Group Investigation}

Penelitian ini dilakukan di SDN Tanggung 1 tepatnya kelas VI pada mata pelajaran Pendidikan Agama Islam yaitu pada saat jam kegiatan belajar mengajar Pendidikan Agama Islam. Penelitian dilakukan dalam dua siklus dengan dua pertemuan setiap siklusnya.

Keterlaksanaan pembelajaran model pembelajaran Group Investigaton dalam penelitian ini ditunjukkan dari (1) hasil observasi aktivitas guru dalam melaksanakan pembelajaran (2) hasil observasi aktivitas siswa dalam mengikuti pembelajaran dan (3) hasil angket siswa setelah dilaksanakan pembelajaran dengan model Group Investigation. Dari refleksi siklus I dan siklus II diperoleh hasil observasi aktivitas guru pada siklus I pertemuan ke-1 mendapatkan presentase $60 \%$ dalam cukup, pertemuan ke-2 mendapatkan persentase $70 \%$ dalam kriteria baik, sehingga rata-rata observasi guru sebesar $65 \%$ pada siklus II pertemuan ke-1 mendapatkan persentase $100 \%$ dalam kriteria sangat baik dan pertemuan ke-2 mendapatkan persentase $100 \%$ dalam kriteria sangat baik dengan rata-rata $100 \%$. Sehingga terdapat kenaikan Siklus I ke Siklus II sebesar 35\%.

Sedangkan hasil observasi aktivitas siswa pada siklus I pertemuan ke-1 sebesar $60 \%$ meningkat $10 \%$ sehingga pada siklus I pertemuan ke-2 menjadi $70 \%$. Rata-rata observasi siswa pada Siklus I sebesar 65\%. Pada siklus II pertemuan ke1 observasi siswa mencapai $90 \%$, pada pertemuan ke-2 meningkat menjadi $100 \%$, ada peningkatan sebesar $10 \%$. Rata-rata observasi siswa sebesar $95 \%$. Peningkatan observasi siswa siklus I ke siklus II sebesar 30\%.

Hasil angket siswa pada Siklus I pertemuan ke-1 sebesar $82 \%$ dan meningkat pada pertemuan ke-2 menjadi $87,3 \%$ terdapat peningkatan sebesar $5,3 \%$ dengan rata-rata hasil angket sebesar $84,65 \%$. Pada Siklus II pertemuan ke- 1 hasil angket sebesar 95\% dan meningkat menjadi 98,2\% pada pertemuan ke- 2 . Ada peningkatan sebesar 3,2\%. Rata-rata perolehn siklus II sebesar 96,6\%. Ini berarti terdapat peningkatan dari siklus I ke siklus II sebesar 12,04\%.

Keterlaksanaan pembelajaran dalam penelitian ini ditunjukkan oleh hasil observasi aktivitas guru sebagai data wajib dan hasil observasi aktivitas siswa sebagai data pendukung serta dilengkapi dengan hasil respon siswa sebagai data peuunjang. Aktivitas siswa dalam pelaksanaan pembelajaran merupakan bentuk respon yang ditunjukkan siswa, dari hasil stimulus yang diberikan guru pada saat melaksanakan pembelajaran.

Data keterlaksanaan pelaksanaan pembelajaran yang dihasilkan dalam penelitian ini selalu menunjukkan kenaikan hasil dan kreteria yang konsisten mulai dari pertemuan ke-1,pertemuan ke-2 siklus I dan pertemuan 1, pertemuan ke-2 siklus II. Berdasarkan indikator keberhasilan yang sudah ditetapkan di bab III dapat diambil kesimpulan bahwa Penerapan Pembelajaran Model Pembelajaran Group Investigation Terbukti efektif diterapkan dalam mata pelajaran Pendidikan Agama Islam khususnya materi Zakat.

\section{Hasil Belajar Siswa Mata Pelajaran Pendidikan Agama Islam Materi Zakat Setelah Dilaksanakan Model Pembelajaran Group Investigation (GI)}

Hasil rata-rata kerja kelompok siklus I pertemuan ke-1 sebesar 75 dan meningkat pada pertemuan ke-2 menjadi 83,33. Rata-rata hasil kerja kelompok 
sebesar 79,16. Hasil rata-rata kerja kelompok siklus II pertemuan ke-1 sebesar 86,67 dan meningkat menjadi 100 pada pertemuan ke-2. Rata-rata hasil kerja kelompok pada siklus II sebesar 93,33.

Hasil ketuntasan belajar dari nilai tes individu siklus I pertemuan ke-1 sebesar $67,65 \%$ dan meningkat pada pertemuan kedua menjadi $73 \%$. Rata-rata hasil nilai ketuntasan belajar dari tes individu sebesar 70,3\%. Hasil nilai ketunasan belajar dari tes individu siklus II pertemuan ke-1 sebesar $76 \%$ dan meningkat menjadi $88 \%$. Rata-rata ketuntasan belajar pada siklus II sebesar $82 \%$.

Berdasarkan data tersebut dapat diketahui bahawa terdapat peningkatan yang konsisten setiap siklusnya. Sehingga dapat kita simpulkan bahwa Penerapan Pembelajaran Model Group Investigation dapat Meningkatkan Hasil Belajar Siswa kelas VI Pada Mata Pelajaran Pendidikan Agama Islam, khususnya materi Zakat.

\section{KESIMPULAN}

Dari hasil kegiatan pembelajaran yang telah dilakukan sebanyak dua siklus dengan masing-masing siklus terdiri dari dua pertemuan dan berdasarkan seluruh pembahasan serta analisis yang telah dilakukan maka dapat diambil simpulan sebagai berikut: 1) Dengan menerapkan model pembelajaran Group Investigation dapat meningkatkan hasil belajar siswa. Hal tersebut ditunjukkan dengan semakin meningkatnya prosentase pada seluruh hasil sumber data yang diperoleh. 2) Peningkatan hasil belajar siswa dengan menerapkan model pembelajaran Group Investigation ditandai dengan peningkatan prosentase hasil kerja kelompok dari siklus I sebesar 79,16 dan meningkat menjadi 86,67 pada siklus II. Hasil ketuntasan belajar pada siklus I sebesar 70,3\% dan meningkat pada siklus II menjadi $82 \%$.

\section{SARAN}

Dari hasil penelitian serta perolehan data dari uraian sebelumnya, agar proses belajar mengajar Pendidikan Agama Islam lebih efektif dan lebih memberikan hasil yang optimal bagi siswa, maka sebagai guru perlu memperhatikan hal-hal sebagai berikut: 1) Bagi guru, Group Investigation dapat menjadi salah satu pilihan model dalam pembelajaran sehari-hari. Guru juga dapat menerapkan model ini untuk materi pelajaran yang lain. Model ini terbukti dapat mengaktifkan proses belajar. 2)Bagi Siswa, Model Pembelajaran Group Investigation terbukti dapat meningkatkan hasil belajar siswa. Siswa sebaiknya tidak perlu takut atau ragu jika ingin mengeluarkan pendapat. Sesama siswa sebaiknya sering berbagi tentang pembelajaran di kelas supaya pembelajaran lebih menyenangkan. 3) Bagi sekolah, sebaiknya menyediakan referensi/buku-buku yang cukup untuk memperluas wawasan guru dan siswa.

\section{DAFTAR RUJUKAN}

Arikunto, S. 2001. Prosedur Penelitian: Suatu Pendekatan Praktek, Jakarta: Rineka Cipta.

Arikunto, S. 2010. Prosedur Penelitian Pendidikan. Jakarta: PT Rineka Cipta.

Dimyati, D. \& Mudjiono. 2006. Belajar Dan Pembelajaran. Cet. ketiga. Jakarta: PT. Rineka Cipta.

Sukmadinata, N. S. 2007. Metode penelitian. Bandung: PT Remaja Rosda Karya. 
Sukidin, B. (2002). Metode Penelitian Kualitatif Perspektif Mikro. Surabaya: Insan Cendekia.

Vierwinto. 2012. Pengaruh Penggunaan Model Pembelajaran Kooperatif Tipe Group Investigation Terhadap Hasil Belajar Pendidikan Kewarganegaraan Siswa Kelas IV SD Negeri Gendongan 03. Skripsi tidak diterbitkan. Salatiga : Program Studi PGSD UKSW

Yudi Wiratama (2014) Model Pembelajaran Kooperatif Tipe Group Investigation (GI). (Online), (http://yudi-wiratama.blogspot.co.id/2014/01/model pembelajaran-kooperatif-tipe.html.), diakses 10 juni 2017. 